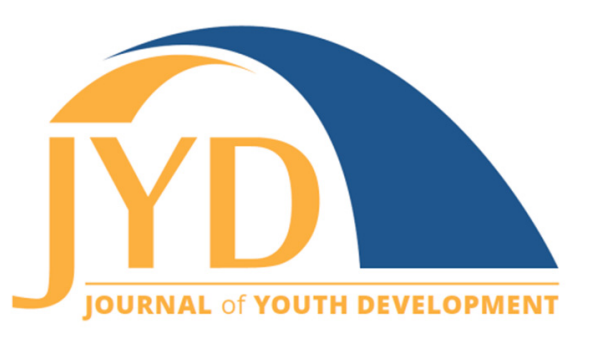

http://jyd. pitt. edu/ | Vol. 13 Issue 4 DOI 10.5195/jyd.2018.724 | ISSN 2325-4017 (online)

\title{
Book Review of The Growing Out-of-School Time Field: Past, Present, and Future
}

Joyce A. Walker

University of Minnesota (retired)

walke007@umn.edu

\section{Abstract}

This first book in the new Current Issues in Out-of-School Time series offers a foundational field perspective on out-of-school time. This volume is designed to inspire thoughtful reflections and critical conversations to further grow, sustain and improve the field by looking at the past and present in order to move forward in innovative ways.

Key words: out-of-school-time field

In the introduction to this provocative anthology, Helen Janc Malone makes her intention clear. The volume is designed to inspire thoughtful reflections and critical conversations on how to further grow and strengthen the out-of-school-time (OST) field by examining both assets and gaps and exploring innovative ways forward. The intent is not so much to provide answers to questions as to stimulate observations and provoke ideas based on expert explorations of the past, present, and future of the OST field. It's a brilliant resource full of insightful lessons to embrace, argue with, and ask, "How does this apply to my work and my profession now and in the future?"

At its core, the book focuses on the many challenges of moving a professional field, originally defined by when and where OST developmental support is offered to children and young people, to a field more broadly defined as what and how OST contexts best support learning and development for the future of the field. The book begins with the past, when the state of the art of organized youth development activities was the topic of the National Research Council

(cc) EY New articles in this journal are licensed under a Creative Commons Attribution 4.0 License. This journal is published by the University Library System, University of Pittsburgh and is cosponsored by the University of Pittsburgh Press. The Journal of Youth Development is the official peer-reviewed publication of the National Association of Extension 4-H Agents and the National AfterSchool Association. 
Book Review: The Growing Out-of-School Time Field

and Institute of Medicine (2002) report, Community Programs to Promote Youth Development. The present is explored in 13 chapters commenting on 15 intervening years of growth, change, and discovery in the field of OST. The three concluding chapters focus on new ways to reframe the what and how of OST's future.

There is good substantive reading here for youth development practitioners, organizational leaders, researchers, and youth development advocates. Digging into the chapters focused on promoting youth development, social and cultural possibilities, professional development, research and evaluation, and advocacy opens new possibilities for the future just as it raises questions about one's own current practice and contributions to the field. The editors have chosen contributing authors who are stalwart researchers and wise practitioners, some newer to the field and some core contributors to the field over the last $20+$ years.

In this reviewer's opinion, this is not a book crafted to be read from beginning to end. The beginning is devoted to the past: the formation of an OST field. The end is focused on recommendations for the future of the field. Bookended by the past and future is the collection of chapters and ideas that have emerged and shaped the present of the OST field. I began with chapter 2 (Simpkins, Liu, \& Dawes) followed by chapter 19 (Pittman). From there it was easyand stimulating - to move around from topic to topic, exploring what interested me at the moment. This approach would work well when teaching a class or working with a learning cohort where students could choose their areas of interest.

A theme emerges: the OST field began on the premise of "when and where" and now poses us with a challenge to move it boldly to a field dedicated to the "what and how" of contexts that foster opportunities and supports for the learning and development of young people. Readers are challenged to conceptualize the field as a vital, essential community resource on its own merits, with a clear identity independent of schooling. This new concept of an OST field, with strong links to family, community and learning institutions would build on a foundation on essential skills, social-emotional learning, life transitions and career and life planning.

Early in the volume, contributor Nikki Pearce Dawes defines OST programs as informal and flexible learning spaces that have potential to support diverse developmental needs of young people. To see OST programs as just an extension of the school day, she proclaims, is a lost opportunity for all kids, but particularly for underserved youth. This rethinking of the philosophy, priorities, strategies and impacts implies a reconceptualized OST and has repercussions for language, identity and core values that articulate what our field stands for, 
Journal of Youth Development | http://jyd.pitt.edu/ | Vol. 13 Issue 4 DOI 10.5195/jyd.2018.724

Book Review: The Growing Out-of-School Time Field

not a description of what we are not. The anthology The Growing Out-of-School Time Field:

Past, Present, and Future presents an excellent starting place for this important conversation.

\section{References}

Malone, H. J. \& Donahue, T. (Eds.). (2017). The Growing Out-of-School Time Field: Past, Present, and Future. Charlotte, NC: Information Age.

National Research Council \& Institute of Medicine. (2002). Community Programs to Promote Youth Development. Washington, DC: The National Academies Press. doi:10.17226/10022 